\title{
Contemporary approaches and challenges of tourism sustainability
}

Please cite this article as:

Popescu, D. 2018. Contemporary Approaches and Challenges of Tourism Sustainability. Amfiteatru Economic, 20(Special No. 12), pp. 830-832.

DOI: 10.24818/EA/2018/S12/830

Tourism has one of the biggest contributions to sustainable development due to the dynamism and growth of this sector with direct implications on economic growth in tourist regions and destinations, as well as to the fact that tourism is based on a direct link between tourists, the industry, the environment and the local communities.

The sustainable development of tourism, like in the case of other industries, has three independent aspects: economic, social-cultural and environmental. This means that sustainable tourism requires the optimal use of resources, minimizing the negative economic, socio-cultural and environmental impact, maximizing benefits for local communities, national economies and nature conservation. As a result, by developing its many forms of concrete manifestation, sustainable tourism ensures the natural and economic integrity of the environment and the rational use of natural and cultural resources, but maintains the potential for future generations.

The positive impact of sustainable tourism is a very important one as it contributes to: increasing the number of jobs; stimulating investment; creating and developing the local infrastructure; establishing intercultural links; obtaining income by capitalizing on natural and cultural resources that can be used for conservation and environmental protection activities.

The importance of the tourism activity and the need for its sustainable development are underlined by the latest statistical data provided by the World Tourism Organization. Thus, in 2017, one in ten jobs belonged to the tourist sector and $10 \%$ of the gross global product was created in the field of tourism. Also, tourism accounted for $7 \%$ of global exports and $30 \%$ of global services` exports in the same year.

For tour operators, the challenge is to find a balance between the sustainable development of tourism, prosperity and people's desire to improve their material and financial conditions, but also to combine the requirements of sustainable development with the growing competition in the field. In this regard, scientists have an important say, and the papers presented in this special issue of Amfiteatru 
Economic attempt to make a contribution to addressing the challenges of sustainable tourism.

Below are some contributions of the articles in this issue of the journal, as follows:

- „CEE-16: a cluster analysis based on tourism competitiveness and correlations with major determinants" has as main objective to identify the main groups of countries at ECE-16 level in terms of tourism competitiveness and to determine the correlations between supply and demand, starting from the attractiveness of tourist destinations from the perspective of tourists;

-,The regional development of the Romanian rural tourism sector" performs an assessment of Romanian rural tourism based on statistical data and using an analysis of the main components for mixed data and cluster analysis, focusing on the regional development poles;

- ,The impact of geopolitical risks on tourism” presents the new context of the impact of geopolitical risks on tourism activities and, in the same context, the article „Analysis of economic growth in tourism under the impact of terrorism and of the waves of refugees" highlights the complexity of the tourist phenomenon and the major factors that characterize it, such as terrorist attacks and invasion of refugees;

-,The fairness of pricing tactics for hotels: perceptions of Romanian customers" makes an analysis of the perception on the tariff tactics practiced in the hotels in Romania and the degree to which these perceptions influence the intention to buy;

- „A study on the Romanians' profile among leisure activities” conducts a research whose aim is to identify and describe what are the favorite activities of Romanians in their free time and what influence does the respondents` profile have on their preferences;

-, The complex relationship between international tourism demand and economic growth: an analysis on central and Eastern European economies" analyzes the relationship between tourism demand and economic growth in terms of the impact of economic growth on the number of international tourist arrivals and international tourist receipts, taking into account a relatively homogeneous group of economies;

- „Involvement of rural tourism operators in the project "Sibiu European Gastronomic Region" aims at promoting gastronomy tourism products that incorporate traditional values, the purpose of the paper being to analyze the preferences of tourists for practicing gastronomy tourism and the involvement of rural tourism operators in the project, taking into account the types of favorite events;

- ,The destination experience through stopover tourism - Bucharest case study" aims to analyze the role of "Stopover" programs in regional tourism development, to identify the characteristics of this new form of tourism and the measures to be taken by the authorities in order to implement it in Romania;

Vol. $20 \cdot$ Special No. $12 \cdot$ November 2018 
- ,Determinants and implications of the tourism multiplier effect in EU economies. Towards a core-periphery pattern?" aims to identify the macroeconomic determinants that are responsible for the high values of the effects of tourism multiplication and to highlight the potential of tourist activity in reducing the disparities that exist between the countries of the European Union;

-, Sharing economy: challenges and opportunities in tourism” aims to determine the opportunities and benefits of the sharing economy in terms of both national and international tourism, as well as the challenges brought to the business environment by the current technological infrastructure;

- ,Social media advertising trends in tourism” highlights the ways in which advertising messages from and about tourism in the social media can quickly have a much improved success rate;

- ,Better brand management through design thinking”, features design and design-centered thinking as elements that support successful brand management, and tourism is taken as a case study, as it is the sector of the economy that is currently registering the world's fastest growth;

- ,Disparities in tourism demand of UNESCO destinations”, presents the disparities in tourism demand in three UNESCO destinations in the Czech Republic and looks for solutions to attract visitors in the context of the sustainable development of the analyzed region.

Tourism, as can be seen from the diversity of topics covered in this issue of Amfiteatru Economic, is a complex area that can certainly be enriched and improved by its approach from a sustainable development perspective.

Delia Popescu, Head of the Tourism and Geography Department, Faculty of Business and Tourism, Bucharest University of Economic Studies 